\title{
ABRANGÊNCIA DA LEI DE IMPROBIDADE ADMINISTRATIVA
}

JOSÉ SÉRGIO SARAIVA MARCELO TOFFANO

ISSUE DOI: $10.21207 / 1983.4225 .593$

\section{RESUMO}

A Lei no 8.429, de 2-6-1992 e alterações, conhecida como Lei de "improbidade administrativa", na verdade dispõe sobre as sanções aplicáveis aos agentes públicos nos casos de enriquecimento ilícito no exercício do mandato, cargo, emprego ou função pública na adminsitração pública direta, indireta ou fundacional. Assim, importante percorrer pelas noções gerais no âmbito do direito administrativo e aspectos relevantes da lei acerca das sanções aplicáveis aos agentes públicos nos casos de enriquecimento ilícito no exercício de mandato, cargo, emprego ou função na administração pública direta, indireta ou fundacional. A atualidade do tema, face ao cenário político vivenciado no País, motiva conhecer os conceitos e definições legais que circunscrevem o tema da improbidade administrativa e as consequências sofridas pelo agente público que causa qualquer tipo de lesão ao erário ou patrimônio público. A base constitucional, prevista por meio do artigo $37, \S 4^{\circ}$, ampara e autoriza a normatização do ordenamento jurídico por meio da referida Lei, permitindo uma ação punitiva do Estado ao agente que pratica atos de improbidade, fixando desde a suspensão dos direitos políticos, dentre outras, até o ressarcimento ao erário, na forma e gradação previstas em lei, sem prejuízo da ação penal cabível. Por meio da mencionada Lei e da ação popular, 
também com previsão constitucional (art. $5^{\circ}$, LXXIII), o ordenamento jurídico nacional dispõe de desses instrumentos processuais para defesa constitucional da moralidade administrativa. A competência para legislar sobre improbidade administrativa, abrangência da Lei e a definição do sujeito passivo e ativo, não fora esquecida, sendo tratadas de modo a identificá-las, enfrentando até mesmo a questão tormentosa sobre os agentes políticos, aplicando ou não a Lei de Improbidade Administrativa, com destaque para jurisprudência do Supremo Tribunal Federal sobre o conflito. Destaca as espécies de ato de improbidade, desde os que importam em enriquecimento ilícito, àqueles que causam prejuízo ao erário e os que atentam contra os princípios da administração pública, bem como as sanções cabíveis para cada um deles, inclusive o dever de declaração de bens e a improbidade administrativa em confronto com o princípio da insignificância. Por fim, ao discorrer sobre o procedimento administrativo, a ação judicial e a prescrição, permitiu concluir sobre noções gerais e como as sanções previstas na Lei n ${ }^{\circ} 8.429 / 92$, que são aplicáveis aos agentes públicos que lesam o erário e o patrimônio público.

Palavras-chave: Constituição Federal. Princípos constitucionais. Lei $\mathrm{n}^{\mathbf{o}}$ 8.429/92. Improbidade Administrativa. Sanções Administrativas, Civis e Criminais.

\section{INTRODUÇÃO}

Neste capítulo, serão apresentadas noções gerais sobre um tema muito importante no âmbito do direito administrativo denominado de "improbidade administrativa". Para tanto, serão expostos os aspectos relevantes existentes na Lei $n^{\circ} 8.429$, de 2 de junho de 1992 que dispõe sobre as sanções aplicáveis aos agentes públicos nos casos de enriquecimento ilícito no exercício de mandato, cargo, emprego ou função na administração pública direta, indireta ou fundacional. Trata-se de um tema de grande importância inclusive pelo cenário político vivenciado no Brasil atualmente.

Deste modo, pretende-se demonstrar os conceitos e definições legais que cercam a temática da improbidade administrativa e as consequências sofridas pelo agente público que causa qualquer tipo de lesão ao erário ou patrimônio público. 


\section{BASE CONSTITUCIONAL}

A preocupação do legislador em punir eventuais atos de improbidade administrativa praticados por agentes públicos está consignada, inclusive, na normativa constitucional, elevando o embate acerca do tema ao nível máximo do ordenamento jurídico brasileiro.

O art. $37, \S 4^{\circ}$ da Constituição Federal apresenta o seguinte teor: "os atos de improbidade administrativa importarão a suspensão dos direitos políticos, a perda da função pública, a indisponibilidade dos bens e o ressarcimento ao erário, na forma e gradação previstas em lei, sem prejuízo da ação penal cabível".

É importante observar que a norma constitucional sob análise se caracteriza por ser de eficácia limitada, pois o seu alcance prático somente foi possível após a promulgação da Lei $\mathrm{n}^{\circ} 8429 / 92$. A referida lei foi responsável por apresentar os contornos concretos do princípio da moralidade administrativa, estampado no art. 37 da Constituição Federal.

Mazza (2013, pp. 455-456) destaca que a Lei $n^{\circ}$ 8429/92 apresenta uma clara afinidade com "o princípio da moralidade administrativa, com base no enunciado no art. 37, caput, da CF de 1988. Na verdade, o princípio da probidade é um subprincípio dentro da noção mais abrangente de moralidade". Adiante, prossegue o jurista que "o dever de punição dos atos de improbidade é também uma imposição do princípio da legalidade".

Ainda sob a ótica constitucional, deve-se analisar também outros dispositivos relacionados com o dever de probidade administrativa. Nesse sentido, citam-se os seguintes:

a) art. 14, § 9": "lei complementar estabelecerá outros casos de inelegibilidade e os prazos de sua cessação, a fim de proteger a probidade administrativa, a moralidade para exercício de mandato considerada vida pregressa do candidato, e a normalidade e legitimidade das eleições contra a influência do poder econômico ou o abuso do exercício de função, cargo ou emprego na administração direta ou indireta";

b) art. 15, V: "é vedada a cassação de direitos políticos, cuja perda ou suspensão só se dará nos casos de: V - improbidade administrativa, nos termos do art. 37, $\S 4^{\circ}$ "; e

c) art. 85, V: "são crimes de responsabilidade os atos do Presidente da República que atentem contra a Constituição Federal e, especialmente, contra: $\mathrm{V}$ - a probidade na administração". 


\section{DEFESA CONSTITUCIONAL DA MORALIDADE ADMINISTRATIVA}

O caput do art. 37 da Constituição Federal vislumbra que "a administração pública direta e indireta de qualquer dos Poderes da União, dos Estados, do Distrito Federal e dos Municípios obedecerá aos princípios de legalidade, impessoalidade, moralidade, publicidade e eficiência".

Com a finalidade de preservar a moralidade administrativa, a Carta Magna apresenta dois instrumentos processuais: a ação popular (art. $5^{\circ}$, LXXIII) e a ação de improbidade administrativa (art. 37, § $4^{\circ}$ ).

Acerca de tais institutos processuais, observa-se que eles possuem diferenças, sendo a legitimidade ativa e os pedidos formulados as principais características diferenciadoras existentes.

A Ação Popular pode ser proposta por qualquer cidadão, ou seja, qualquer pessoa física em pleno gozo de seus direitos políticos. Seu pedido tem por escopo a anulação do ato lesivo à moralidade e a condenação do réu ao ressarcimento pelas perdas e danos que causou, conforme teor do art. 11 da Lei $\mathrm{n}^{\circ}$ 4.717/65.

A Ação de Improbidade Administrativa, somente pode ser proposta por representante do Ministério Público ou pessoa jurídica interessada (art. 17 da Lei ${ }^{\circ}$ 8.429/92). O seu pedido poderá englobar: a perda dos bens ou valores acrescidos ilicitamente; o ressarcimento integral do dano; a perda da função pública; a suspensão dos direitos políticos; a multa civil; e a proibição de contratar com o Poder Público ou receber benefícios ou incentivos fiscais ou creditícios.

Importante frisar que a legislação em vigência não impede a propositura simultânea de ação popular e ação de improbidade administrativa motivadas pela mesma conduta lesiva, independentemente da natureza.

\section{COMPETÊNCIA PARA LEGISLAR SOBRE IMPROBIDADE ADMINISTRATIVA}

Ao analisar a competência legislativa para elaborar leis punitivas para a prática de atos de improbidade administrativa depreende-se que a competência é privativa da União. 


\section{$4 \quad$ ABRANGÊNCIA DA LEI № 8.429/92}

De acordo com o art. $1^{\circ}$ da Lei $n^{\circ} 8.429 / 92$ sua aplicação alcança "atos de improbidade praticados por qualquer agente público, servidor ou não, contra a administração direta, indireta ou fundacional de qualquer dos Poderes da União, dos Estados, do Distrito Federal, dos Municípios, de Território, de empresa incorporada ao patrimônio público ou de entidade para cuja criação ou custeio o erário haja concorrido ou concorra com mais de $50 \%$ do patrimônio ou da receita anual”.

O parágrafo único do mesmo dispositivo estende as penalidades previstas na lei "aos atos de improbidade praticados contra o patrimônio de entidade que receba subvenção, benefício ou incentivo, fiscal ou creditício, de órgão público bem como daquelas para cuja criação ou custeio o erário haja concorrido ou concorra com menos de $50 \%$ do patrimônio ou da receita anual, limitando-se, nestes casos, a sanção patrimonial à repercussão do ilícito sobre a contribuição dos cofres públicos".

\section{SUJEITO PASSIVO DO ATO DE IMPROBIDADE}

Nos termos da Lei $\mathrm{n}^{\circ}$ 8.429/92, podem ser sujeitos passivos as pessoas jurídicas organizadas nas seguintes categorias:

a) Administração pública direta: composta pelas pessoas federativas, ou seja, União, Estados, Distrito Federal, Municípios e Territórios;

b) Administração pública indireta: autarquias, fundações públicas, associações públicas, empresas públicas, sociedades de economia mista e fundações governamentais;

c) Empresas incorporadas ao patrimônio público ou de entidade cuja criação ou custeio o erário haja concorrido ou concorra com mais de $50 \%$ do patrimônio ou da receita anual, ou seja, também é aplicável às empresas governamentais (denominadas empresas públicas e sociedades de economia mista).

d) Entidades que recebam subvenção, benefício ou incentivo, fiscal ou creditício, provenientes de órgãos públicos. Trata-se das pessoas jurídicas privadas, não pertencentes ao Estado, inclusive, as pessoas jurídicas integrantes do Terceiro Setor.

e) Entidades cuja criação ou custeio o erário haja concorrido ou concorra com menos de $50 \%$ do patrimônio ou da receita anual, ou seja, 
as empresas privadas com participação estatal, inclusive, as sociedades criadas com o propósito específico de gerir parcerias público-privadas.

\section{SUJEITO ATIVO DO ATO DE IMPROBIDADE}

Em atenção ao teor do art. $1^{\circ}$ da Lei $n^{\circ} 8.429 / 92$, verifica-se que $\mathrm{o}$ ato de improbidade administrativa poderá ser praticado por "qualquer agente público, servidor ou não", ou seja, atinge todas as categorias de servidores (estatutários, celetistas, temporários, agentes políticos, etc), além de ser aplicada às entidades do terceiro setor, aos funcionários e dirigentes de sindicatos, e às pessoas integrantes dos serviços sociais paraestatais (componentes do sistema " $\mathrm{S}$ ").

$\mathrm{O}$ art. $2^{\circ}$ da Lei $n^{\circ} 8.429 / 92$ esclarece que se entende por agente público, "todo aquele que exerce, ainda que transitoriamente ou sem remuneração, por eleição, nomeação, designação, contratação ou qualquer outra forma de investidura ou vínculo, mandato, cargo, emprego ou função" relacionadas com as entidades citados no art. $1^{\circ}$, conforme indicado no parágrafo anterior.

Cumpre observar que o art. $3^{\circ}$ da Lei $n^{\circ} 8.429 / 92$ expande a tipificação da lei para outras figuras que não são qualificadas como agentes públicos. Assim sendo, a lei objeto de estudo também é aplicada ao agente que induza ou concorra para a prática do ato de improbidade ou que receba algum tipo de benefício (direto ou indireto) decorrente de tal prática.

Por fim, mostra-se importante ressaltar que, em caso de falecimento de um agente que tenha cometido atos de improbidade, seu espólio responderá pela infração realizada até o limite do valor da herança existente, proporcionando o devido ressarcimento pelo dano, conforme teor do art. $8^{\circ}$ da Lei ${ }^{\circ} 8.429 / 92$.

\section{A QUESTÃO DOS AGENTES POLÍTICOS}

Um ponto interessante na Lei $n^{\circ} 8.429 / 92$ que merece observação é a sua aplicação aos "agentes políticos". Di Pietro explica que se entende por agente político, "no direito brasileiro, apenas os Chefes dos Poderes 
Executivos federal, estadual e municipal, os Ministros e Secretários de Estado, além de Senadores, Deputados e Vereadores". ${ }^{1}$

Embora exista certo conflito de entendimento sobre a aplicação da Lei $\mathrm{n}^{\circ} 8.429 / 92$ aos agentes políticos, entende-se pela sua possibilidade legal. Nesse sentido, verifica-se, inclusive, que o art. 23 de referida legislação trata sobre o "exercício de mandato", corroborando com a tese permissiva.

A Constituição Federal não admite a concorrência entre dois regimes de responsabilidade político-administrativa para os agentes políticos: o previsto no art. $37, \S 4^{\circ}$ (regulado pela Lei $n^{\circ} 8.429 / 1992$ ) e o regime fixado no art. 102, I, c, (disciplinado pela Lei $\left.n^{\circ} 1.079 / 1950\right){ }^{2}$

${ }^{1}$ DI PIETRO. Maria Sylvia Zanella. Direito Administrativo. 13 ${ }^{a}$ ed. São Paulo: Atlas, 2001. p. 417.

${ }^{2}$ Nesse sentido, é o entendimento firmado pelo Supremo Tribunal Federal, conforme segue: “CONSTITUCIONAL. ADMINISTRATIVO. AÇÃO CIVIL PÚBLICA POR ATOS DE IMPROBIDADE ADMINISTRATIVA. PREFEITO MUNICIPAL. AGENTE POLÍTICO. DESVIO E APLICAÇÃO INDEVIDA DE RECURSOS DO FUNDEF. LIBERAÇÃO DE VERBAS SEM PRÉVIA LICITAÇÃO. FRAUDE EM PROCESSOS LICITATÓRIOS. DESNECESSIDADE DE LESÃO PATRIMONIAL AO ERÁRIO PARA CARACTERIZAÇAO DE ATO DE IMPROBIDADE ADMINISTRATIVA QUE VIOLE PRINCÍPIOS ADMINISTRATIVOS. [...] A questão suscitada no recurso versa sobre a possibilidade de processamento e julgamento de prefeitos, por atos de improbidade administrativa, com fundamento na Lei $n^{\circ} 8.429 / 92$. Não se desconhece que esta Corte, no julgamento da Rcl $n^{\circ}$ 2.138 (Rel. Min. NELSON JOBIM, Plenário, DJe de 18.4.2008, Ementário nº 2315-1), decidiu haver distinção entre o regime de responsabilidade dos agentes políticos e o dos demais agentes públicos. Julgo, todavia, ser, mais que oportuna, necessária deliberação desta Corte sobre a possibilidade de extensão dos fundamentos adotados no precedente ao caso de que ora se cuida, porquanto cada uma dessas causas versa sobre autoridades públicas diferentes (Ministros de Estado e Prefeitos), normas específicas de regência dos crimes de responsabilidade (Lei $n^{\circ}$ 1.079/1950 e Decreto-Lei $n^{\circ}$ 201/1967) e regramento constitucional próprio de cada autoridade. E tem sido frequentes recursos acerca da mesma matéria, de intuitivo interesse político e social. Ademais, ressalto o fato relevante de que a $\mathrm{Rcl} \mathrm{n}^{\circ}$ 2.138 foi decidida por escassa maioria de apenas um voto, sem que cinco dos atuais Ministros, AYRES BRITTO, RICARDO LEWANDOWSKI, DIAS TOFFOLI, LUIZ FUX e ROSA WEBER, tenham votado sobre o mérito, em razão de já o terem feito os antecessores. A questão, portanto, transcende os limites subjetivos da causa, apresentando relevância política, jurídica e social, de modo que sua decisão produzirá inevitável repercussão de ordem geral. 3. Ante o exposto, considero presente a repercussão geral da questão. O art. 328 do RISTF autoriza a devolução dos recursos extraordinários e dos agravos de instrumento aos Tribunais ou Turmas Recursais de origem para os fins previstos no art. 543-B do CPC. Devolvam-se os autos à Corte de origem" (STF - Rcl. no 2138 DF , Tribunal Pleno, Rel. Min. Nelson Jobim, DJ: 13/06/2007). 
A impossibilidade de concorrência entre dois regimes de responsabilidade político-administrativa deverá ser imputada também aos prefeitos municipais, conforme decisão do Supremo Tribunal Federal proferida no ARE 644.749:

CONSTITUCIONAL. ADMINISTRATIVO. AÇÃO CIVIL PÚBLICA POR ATOS DE IMPROBIDADE ADMINISTRATIVA. PREFEITO MUNICIPAL. AGENTE POLÍTICO. DESVIO E APLICAÇÃO INDEVIDA DE RECURSOS DO FUNDEF. LIBERAÇÃO DE VERBAS SEM PRÉVIA LICITAÇÃO. FRAUDE EM PROCESSOS

LICITATÓRIOS. DESNECESSIDADE DE LESÃO PATRIMONIAL AO ERÁRIO PARA CARACTERIZAÇAO DE ATO DE IMPROBIDADE ADMINISTRATIVA QUE VIOLE PRINCÍPIOS ADMINISTRATIVOS. [...] A questão suscitada no recurso versa sobre a possibilidade de processamento e julgamento de prefeitos, por atos de improbidade administrativa, com fundamento na Lei $\mathrm{n}^{\circ} 8.429 / 92$.

Não se desconhece que esta Corte, no julgamento da Rcl n 2.138 (Rel. Min. NELSON JOBIM, Plenário, DJe de 18.4.2008, Ementário $n^{\circ}$ 2315-1), decidiu haver distinção entre o regime de responsabilidade dos agentes políticos e o dos demais agentes públicos. Julgo, todavia, ser, mais que oportuna, necessária deliberação desta Corte sobre a possibilidade de extensão dos fundamentos adotados no precedente ao caso de que ora se cuida, porquanto cada uma dessas causas versa sobre autoridades públicas diferentes (Ministros de Estado e Prefeitos), normas específicas de regência dos crimes de responsabilidade (Lei ${ }^{\circ}$ 1.079/1950 e Decreto-Lei ${ }^{\circ}$ 201/1967) e regramento constitucional próprio de cada autoridade. E tem sido frequentes recursos acerca da mesma matéria, de intuitivo interesse político e social.

Ademais, ressalto o fato relevante de que a $\mathrm{Rcl} \mathrm{n}^{\circ}$ 2.138 foi decidida por escassa maioria de apenas um voto, sem que cinco dos atuais Ministros, AYRES BRITTO, RICARDO LEWANDOWSKI, DIAS TOFFOLI, LUIZ FUX e ROSA WEBER, tenham 
votado sobre o mérito, em razão de já o terem feito os antecessores. A questão, portanto, transcende os limites subjetivos da causa, apresentando relevância política, jurídica e social, de modo que sua decisão produzirá inevitável repercussão de ordem geral.

3. Ante o exposto, considero presente a repercussão geral da questão. $\mathrm{O}$ art. 328 do RISTF autoriza a devolução dos recursos extraordinários e dos agravos de instrumento aos Tribunais ou Turmas Recursais de origem para os fins previstos no art. 543-B do CPC. Devolvam-se os autos à Corte de origem". ${ }^{3}$

Essa é a razão pela qual os prefeitos, embora também sejam agentes políticos, não se enquadram na ressalva, e, logo, se submetem à lei de improbidade administrativa, sujeitando-se, ainda, à ação penal por crime de responsabilidade, na forma do Decreto-Lei ${ }^{\circ}$ 201/67, em decorrência do mesmo fato.

\section{ESPÉCIES DE ATO DE IMPROBIDADE}

A Lei ${ }^{\circ} 8.429 / 92$ apresenta um rol exemplificativo de condutas que possam caracterizar o ato de improbidade administrativa. Esse rol está previsto nos arts. $9^{\circ}$ ao 11 , dividindo os atos em 3 (três) classes distintas, conforme a gravidade do comportamento adotado.

\subsection{ATOS DE IMPROBIDADE ADMINISTRATIVA QUE IMPORTAM ENRIQUECIMENTO ILÍCITO (ART. 9²)}

A primeira categoria de ato de improbidade refere-se à prática de enriquecimento ilícito, sendo este considerado o tipo mais grave, pois se refere a hipóteses em que o agente público consegue uma "vantagem patrimonial indevida em razão do exercício de cargo, mandato, função, emprego ou atividade pública", conforme previsto no art. $9^{\circ}$ da Lei $n^{\circ}$ $8.429 / 92$.

\footnotetext{
${ }^{3}$ STF - ARE 644.749 DF, Tribunal Pleno, Rela. Mina. Rosa Weber, DJ: 10/09/2012
} 
O rol exemplificativo de atos de improbidade que importam em enriquecimento ilícito está previsto em 12 (doze) incisos, conforme segue:

I - receber, para si ou para outrem, dinheiro, bem móvel ou imóvel, ou qualquer outra vantagem econômica, direta ou indireta, a título de comissão, percentagem, gratificação ou presente de quem tenha interesse, direto ou indireto, que possa ser atingido ou amparado por ação ou omissão decorrente das atribuições do agente público;

II - perceber vantagem econômica, direta ou indireta, para facilitar a aquisição, permuta ou locação de bem móvel ou imóvel, ou a contratação de serviços pelas entidades referidas no art. $1^{\circ}$ por preço superior ao valor de mercado;

III - perceber vantagem econômica, direta ou indireta, para facilitar a alienação, permuta ou locação de bem público ou o fornecimento de serviço por ente estatal por preço inferior ao valor de mercado;

IV - utilizar, em obra ou serviço particular, veículos, máquinas, equipamentos ou material de qualquer natureza, de propriedade ou à disposição de qualquer das entidades mencionadas no art. $1^{\circ}$ desta lei, bem como o trabalho de servidores públicos, empregados ou terceiros contratados por essas entidades;

$\mathrm{V}$ - receber vantagem econômica de qualquer natureza, direta ou indireta, para tolerar a exploração ou a prática de jogos de azar, de lenocínio, de narcotráfico, de contrabando, de usura ou de qualquer outra atividade ilícita, ou aceitar promessa de tal vantagem;

VI - receber vantagem econômica de qualquer natureza, direta ou indireta, para fazer declaração falsa sobre medição ou avaliação em obras públicas ou qualquer outro serviço, ou sobre quantidade, peso, medida, qualidade ou característica de mercadorias ou bens fornecidos a qualquer das entidades mencionadas no art. $1^{\circ}$ desta lei;

VII - adquirir, para si ou para outrem, no exercício de mandato, cargo, emprego ou função pública, bens de qualquer natureza cujo valor seja desproporcional à evolução do patrimônio ou à renda do agente público; 
VIII - aceitar emprego, comissão ou exercer atividade de consultoria ou assessoramento para pessoa física ou jurídica que tenha interesse suscetível de ser atingido ou amparado por ação ou omissão decorrente das atribuições do agente público, durante a atividade; IX - perceber vantagem econômica para intermediar a liberação ou aplicação de verba pública de qualquer natureza;

$X$ - receber vantagem econômica de qualquer natureza, direta ou indiretamente, para omitir ato de ofício, providência ou declaração a que esteja obrigado;

XI - incorporar, por qualquer forma, ao seu patrimônio bens, rendas, verbas ou valores integrantes do acervo patrimonial das entidades mencionadas no art. $1^{\circ}$ desta lei;

XII - usar, em proveito próprio, bens, rendas, verbas ou valores integrantes do acervo patrimonial das entidades mencionadas no art. $1^{\circ}$ desta lei.

Nesse contexto, Neiva explica ser necessária a configuração de enriquecimento patrimonial indevido do agente, "eis que se houver vantagem diversa da patrimonial, a improbidade existirá, mas terá adequação nos arts. 11 ou $10^{\circ}$, conforme o caso". 4

Cumpre ressaltar que a modalidade de atividade que importa em enriquecimento ilícito não comporta a possibilidade da conduta culposa do agente público. Assim sendo, o ato de improbidade deve ser consciente, configurando a sua antijuridicidade. ${ }^{5}$

Importante esclarecer que o elemento volitivo constituinte do ato de improbidade administrativa que proporciona o enriquecimento ilícito do agente público é o dolo, em especial pelo fato de o ordenamento jurídico em vigência vislumbrar a necessidade de se verificar o elemento subjetivo de responsabilidade civil.

\footnotetext{
${ }^{4}$ NEIVA, José Antônio Lisboa. Improbidade administrativa: legislação comentada artigo por artigo- doutrina, legislação e jurisprudência. $2^{a}$ edição, Niterói- RJ: Ed. Impetus, 2011. p. 66.

${ }^{5}$ FAZZIO JÚNIOR, Waldo. Improbidade Administrativa e Crimes de Prefeitos. São Paulo: Editora Atlas. 2012. p. 148.
} 


\subsubsection{SANÇÕES CABÍVEIS}

Conforme previsto no art. 12, I, da Lei $\mathrm{n}^{\circ}$ 8.429/92, independentemente das sanções penais, civis e administrativas previstas na legislação específica, está o responsável pelo ato de improbidade sujeito à "perda dos bens ou valores acrescidos ilicitamente ao patrimônio, ressarcimento integral do dano, quando houver, perda da função pública, suspensão dos direitos políticos de oito a dez anos, pagamento de multa civil de até três vezes o valor do acréscimo patrimonial e proibição de contratar com o Poder Público ou receber benefícios ou incentivos fiscais ou creditícios, direta ou indiretamente, ainda que por intermédio de pessoa jurídica da qual seja sócio majoritário, pelo prazo de 10 (dez) anos".

\subsection{ATOS DE IMPROBIDADE ADMINISTRATIVA QUE CAUSAM PREJUÍZO AO ERÁRIO (ART. 10)}

A segunda categoria de atos de improbidade tipifica as hipóteses em que o agente público causa prejuízo ao erário. Essa modalidade é considerada de gravidade intermediária e qualifica o ato que "causa lesão ao erário qualquer ação ou omissão, dolosa ou culposa, ensejador da perda patrimonial, de desvio, de apropriação, de malbaratamento ou de dilapidação dos bens ou de haveres das entidades mencionadas na Lei”, conforme previsto no art. 10 da Lei ${ }^{\circ}$ 8.429/92.

Nesse diapasão, o art. 10 apresenta um rol exemplificativo dividido em 15 (quinze) incisos, a saber:

I - facilitar ou concorrer por qualquer forma para a incorporação ao patrimônio particular, de pessoa física ou jurídica, de bens, rendas, verbas ou valores integrantes do acervo patrimonial das entidades mencionadas no art. $1^{\circ}$ desta lei;

II - permitir ou concorrer para que pessoa física ou jurídica privada utilize bens, rendas, verbas ou valores integrantes do acervo patrimonial das entidades mencionadas no art. $1^{\circ}$ desta lei, sem a observância das formalidades legais ou regulamentares aplicáveis à espécie; 
III - doar à pessoa física ou jurídica bem como ao ente despersonalizado, ainda que de fins educativos ou assistências, bens, rendas, verbas ou valores do patrimônio de qualquer das entidades mencionadas no art. $1^{\circ}$ desta lei, sem observância das formalidades legais e regulamentares aplicáveis à espécie;

IV - permitir ou facilitar a alienação, permuta ou locação de bem integrante do patrimônio de qualquer das entidades referidas no art. $1^{\circ}$ desta lei, ou ainda a prestação de serviço por parte delas, por preço inferior ao de mercado;

V - permitir ou facilitar a aquisição, permuta ou locação de bem ou serviço por preço superior ao de mercado;

VI - realizar operação financeira sem observância das normas legais e regulamentares ou aceitar garantia insuficiente ou inidônea;

VII - conceder benefício administrativo ou fiscal sem a observância das formalidades legais ou regulamentares aplicáveis à espécie;

VIII - frustrar a licitude de processo licitatório ou dispensá-lo indevidamente; (Vide Lei $\mathrm{n}^{\circ}$ 13.019, de 2014); (Vigência)

IX - ordenar ou permitir a realização de despesas não autorizadas em lei ou regulamento;

$\mathrm{X}$ - agir negligentemente na arrecadação de tributo ou renda, bem como no que diz respeito à conservação do patrimônio público;

XI - liberar verba pública sem a estrita observância das normas pertinentes ou influir de qualquer forma para a sua aplicação irregular;

XII - permitir, facilitar ou concorrer para que terceiro se enriqueça ilicitamente;

XIII - permitir que se utilize, em obra ou serviço particular, veículos, máquinas, equipamentos ou material de qualquer natureza, de propriedade ou à disposição de qualquer das entidades mencionadas no art. $1^{\circ}$ desta lei, bem como o trabalho de servidor público, empregados ou terceiros contratados por essas entidades.

XIV - celebrar contrato ou outro instrumento que tenha por objeto a prestação de serviços públicos por 
meio da gestão associada sem observar as formalidades previstas na lei;

$\mathrm{XV}$ - celebrar contrato de rateio de consórcio público sem suficiente e prévia dotação orçamentária, ou sem observar as formalidades previstas na lei.

$\mathrm{O}$ art. 10 da Lei $\mathrm{n}^{\circ} 8.429 / 92$ analisa o aspecto objetivo do ato praticado, ou seja, "as atividades ímprobas devem, para sua observância, acarretar prejuízos ao patrimônio público econômico". Ademais, o presente dispositivo não busca verificar se o agente público auferiu alguma vantagem para si, mas analisa se o comportamento adotado causou qualquer tipo de prejuízo econômico ao Poder Público. ${ }^{6}$

Importante ressaltar que se trata da única hipótese que permite o elemento subjetivo de culpa para a configuração do ato ímprobo.

\subsubsection{SANÇÕES CABÍVEIS}

Conforme previsto no art. 12 , II, da Lei $\mathrm{n}^{\circ}$ 8.429/92, independentemente das sanções penais, civis e administrativas previstas na legislação específica, está o responsável pelo ato de improbidade sujeito "ao ressarcimento integral do dano, perda dos bens ou valores acrescidos ilicitamente ao patrimônio, se concorrer esta circunstância, perda da função pública, suspensão dos direitos políticos de cinco a oito anos, pagamento de multa civil de até duas vezes o valor do dano e proibição de contratar com o Poder Público ou receber benefícios ou incentivos fiscais ou creditícios, direta ou indiretamente, ainda que por intermédio de pessoa jurídica da qual seja sócio majoritário, pelo prazo de 5 (cinco) anos".

\subsection{ATOS DE IMPROBIDADE QUE ATENTAM CONTRA OS PRINCÍPIOS DA ADMINISTRAÇÃO PÚBLICA (ART. 11)}

Por fim, a Lei $\mathrm{n}^{\circ}$ 8.429/92 categoriza os atos de improbidade que atentam contra o princípio da administração pública, ou seja, aqueles que

\footnotetext{
${ }^{6}$ FAZZIO JÚNIOR, Waldo. Improbidade Administrativa e Crimes de Prefeitos. São Paulo: Editora Atlas. 2012. p. 200.
} 
violam os deveres de honestidade, imparcialidade, legalidade, e lealdade às instituições. Trata-se da modalidade menos gravosa tipificada na lei sob análise e o art. 11 apresenta o seguinte rol exemplificativo de condutas consideradas ímprobas em sentido estrito:

I - praticar ato visando fim proibido em lei ou regulamento ou diverso daquele previsto, na regra de competência;

II - retardar ou deixar de praticar, indevidamente, ato de ofício;

III - revelar fato ou circunstância de que tem ciência em razão das atribuições e que deva permanecer em segredo;

IV - negar publicidade aos atos oficiais;

$\mathrm{V}$ - frustrar a licitude de concurso público;

VI - deixar de prestar contas quando esteja obrigado a fazê-lo;

VII - revelar ou permitir que chegue ao conhecimento de terceiro, antes da respectiva divulgação oficial, teor de medida política ou econômica capaz de afetar o preço de mercadoria, bem ou serviço.

Assim sendo, a improbidade administrativa, em sentido estrito, abrange os atos comissivos ou omissos que violem os princípios da Administração Pública, na forma apontada nos incisos acima. Todavia, Neiva (2011, p. 9) pondera que:

O art. 11 da lei $n^{\circ} 8429 / 1992$ exige adequada interpretação, pois não seria razoável entender que a simples violação ao princípio da legalidade, por si só, ensejaria a caracterização de ato improbo. Seria confundir os conceitos de improbidade administrativa e de legalidade.

Destarte, entende-se que a configuração da improbidade administrativa não se refere, exclusivamente, à legalidade, conforme ensina Bitencourt Neto (2005, p.129):

Desse modo, nem toda ofensa à legalidade configura ato de improbidade administrativa. Ainda que demonstrada a intenção do agente no afastamento do princípio, a conduta deve ser julgada em função das circunstâncias do caso, a fim de que sejam perquiridas as razões da escolha e 
a existência de valões mais relevantes, que conduziram à aplicação de outros princípios do sistema, igualmente válidos. ${ }^{7}$

Sobre o tema, Mazza apresenta a seguinte ressalva "a caracterização do ato de improbidade não exige a ocorrência de lesão financeira ao erário. Embora na linguagem comum "improbidade" seja quase um sinônimo de "desvio de verbas públicas", o art. 11 da Lei de Improbidade permite concluir que pode haver improbidade administrativa no simples descumprimento de princípio administrativo, sem qualquer prejuízo financeiro aos cofres públicos. Os atos de improbidade descritos na LIA envolvem sempre uma lesão presumida ao interesse público". ${ }^{8}$

Por fim, observa-se que o ato de improbidade qualificado neste inciso somente poderá ocorrer na modalidade dolosa.

\subsubsection{SANÇÕES CABÍVEIS}

Conforme previsto no art. 12, III da Lei $\mathrm{n}^{\circ} 8.429 / 92$, independentemente das sanções penais, civis e administrativas previstas na legislação específica, está o responsável pelo ato de improbidade sujeito "ao ressarcimento integral do dano, se houver, perda da função pública, suspensão dos direitos políticos de três a cinco anos, pagamento de multa civil de até cem vezes o valor da remuneração percebida pelo agente e proibição de contratar com o Poder Público ou receber benefícios ou incentivos fiscais ou creditícios, direta ou indiretamente, ainda que por intermédio de pessoa jurídica da qual seja sócio majoritário, pelo prazo de 3 (três) anos”.

\section{DECLARAÇÃO DE BENS}

$\mathrm{O}$ art. 13 da Lei $\mathrm{n}^{\circ}$ 8.429/92 determina que "a posse e o exercício de agente público ficam condicionados à apresentação de declaração dos bens e valores que compõem o seu patrimônio privado, a fim de ser arquivada no serviço de pessoal competente".

${ }^{7}$ BITENCOURT NETO, Eurico. Improbidade administrativa e violação de princípios. Belo Horizonte: Del Rey, 2005. p. 129.

${ }^{8}$ MAZZA, Alexandre, Manual de Direito Administrativo. $3^{\text {a }}$ ed. São Paulo: Saraiva, 2013. p. 461. 
A declaração "será anualmente atualizada e na data em que o agente público deixar o exercício do mandato, cargo, emprego ou função" e deverá compreender imóveis, móveis, semoventes, dinheiro, títulos, ações, e qualquer outra espécie de bens e valores patrimoniais, localizado no País ou no exterior e, quando for o caso, abrangerá os bens e valores patrimoniais do cônjuge ou companheiro, dos filhos e de outras pessoas que vivam sob a dependência econômica do declarante, excluídos apenas os objetos e utensílios de uso doméstico, na forma do $\S 1^{\circ}$ do art. 13 da Lei $n^{\circ} 8.429 / 92$.

É importante observar que a recusa no fornecimento da declaração, ou a prestação de qualquer informação falsa resultará na demissão do agente público, além da aplicação das demais sanções cabíveis.

\section{IMPROBIDADE ADMINISTRATIVA E PRINCÍPIO DA INSIGNIFICÂNCIA}

Um ponto interessante da Lei $n^{\circ} 8.429 / 92$ é a impossibilidade de aplicação do princípio da insignificância e a teoria dos delitos de bagatela para os atos de improbidade administrativa.

Nesse sentido, o Superior Tribunal de Justiça firmou o entendimento de que nos atos de improbidade está em jogo a moralidade administrativa, "não se admitindo que haja apenas um pouco de ofensa, sendo incabível o julgamento basear-se exclusivamente na ótica econômica".

\footnotetext{
${ }^{9}$ Nesse sentido, é o teor do seguinte julgado: PROCESSUAL CIVIL. AÇÃO CIVIL PÚBLICA. PRINCÍPIO DA MORALIDADE ADMINISTRATIVA. IMPROBIDADE ADMINISTRATIVA. MERA IRREGULARIDADE ADMINISTRATIVA. PRINCÍPIO DA INSIGNIFICÂNCIA. DISTINÇÃO ENTRE JUIIZO DE IMPROBIDADE DA CONDUTA E JUÍZO DE DOSIMETRIA DA SANÇÃO. 1. Hipótese em que o Ministério Público do Estado do Rio Grande do Sul ajuizou Ação Civil Pública contra o Chefe de Gabinete do Município de Vacaria/RS, por ter utilizado veículo de propriedade municipal e força de trabalho de três membros da Guarda Municipal para transportar utensílios e bens particulares. 2. Não se deve trivializar a Lei da Improbidade Administrativa, seja porque a severidade das punições nela previstas recomenda cautela e equilíbrio na sua aplicação, seja porque os remédios jurídicos para as desconformidades entre o ideal e o real da Administração brasileira não se resumem às sanções impostas ao administrador, tanto mais quando nosso ordenamento atribui ao juiz, pela ferramenta da Ação Civil Pública, amplos e genéricos poderes de editar provimentos mandamentais de regularização do funcionamento das atividades do Estado. 3. A implementação judicial da Lei da Improbidade Administrativa segue uma espécie de silogismo - concretizado em dois momentos, distintos e consecutivos, da sentença ou acórdão - que deságua no dispositivo final de condenação: o juízo de improbidade da
} 
conduta (= premissa maior) e o juízo de dosimetria da sanção (= premissa menor). 4. Para que o defeito de uma conduta seja considerado mera irregularidade administrativa, exigese valoração nos planos quantitativo e qualitativo, com atenção especial para os bens jurídicos tutelados pela Constituição, pela Lei da Improbidade Administrativa, pela Lei das Licitações, pela Lei da Responsabilidade Fiscal e por outras normas aplicáveis à espécie. Trata-se de exame que deve ser minucioso, sob pena de transmudar-se a irregularidade administrativa banal ou trivial, noção que legitimamente suaviza a severidade da Lei da Improbidade Administrativa, em senha para a impunidade, business as usual. 5. Nem toda irregularidade administrativa caracteriza improbidade, nem se confunde o administrador inábil com o administrador ímprobo. Contudo, se o juiz, mesmo que implicitamente, declara ou insinua ser ímproba a conduta do agente, ou reconhece violação aos bens e valores protegidos pela Lei da Improbidade Administrativa (= juízo de improbidade da conduta), já não lhe é facultado - sob o influxo do princípio da insignificância, mormente se por "insignificância" se entender somente o impacto monetário direto da conduta nos cofres públicos - evitar o juízo de dosimetria da sanção, pois seria o mesmo que, por inteiro, excluir (e não apenas dosar) as penas legalmente previstas. 6. Iniqüidade é tanto punir como improbidade, quando desnecessário (por atipicidade, p. ex.) ou além do necessário (= iniqüidade individual), como absolver comportamento social e legalmente reprovado (= iniqüidade coletiva), incompatível com o março constitucional e a legislação que consagram e garantem os princípios estruturantes da boa administração. 7. O juiz, na medida da reprimenda (= juízo de dosimetria da sanção), deve levar em conta a gravidade, ou não, da conduta do agente, sob o manto dos princípios da razoabilidade e da proporcionalidade, que têm necessária e ampla incidência no campo da Lei da Improbidade Administrativa. 8. Como o seu próprio nomen iuris indica, a Lei 8.429/92 tem na moralidade administrativa o bem jurídico protegido por excelência, valor abstrato e intangível, nem sempre reduzido ou reduzível à moeda corrente. 9. A conduta ímproba não é apenas aquela que causa dano financeiro ao Erário. Se assim fosse, a Lei da Improbidade Administrativa se resumiria ao art. 10, emparedados e esvaziados de sentido, por essa ótica, os arts. 9 e 11. Logo, sobretudo no campo dos princípios administrativos, não há como aplicar a lei com calculadora na mão, tudo expressando, ou querendo expressar, na forma de reais e centavos. 10. A insatisfação dos eminentes julgadores do Tribunal de Justiça do Rio Grande do Sul com o resultado do juízo de dosimetria da sanção, efetuado pela sentença, levou-os, em momento inoportuno (isto é, após eles mesmos reconhecerem implicitamente a improbidade), a invalidar ou tornar sem efeito o próprio juízo de improbidade da conduta, um equívoco nos planos técnico, lógico e jurídico. 11. A Quinta Turma do STJ, em relação a crime de responsabilidade, já se pronunciou no sentido de que "deve ser afastada a aplicação do princípio da insignificância, não obstante a pequena quantia desviada, diante da própria condição de Prefeito do réu, de quem se exige um comportamento adequado, isto é, dentro do que a sociedade considera correto, do ponto de vista ético e moral." (REsp 769317/AL, Rel. Ministro Gilson Dipp, Quinta Turma, DJ 27/3/2006). Ora, se é assim no campo penal, com maior razão no universo da Lei de Improbidade Administrativa, que tem caráter civil. 12. Recurso Especial provido, somente para restabelecer a multa civil de $\mathrm{R} \$ 1.500,00$ (um mil e quinhentos reais), afastadas as sanções de suspensão de direitos políticos e proibição de contratar com o Poder Público, pretendidas originalmente pelo Ministério Público “(STJ - REsp 892818 RS 2006/0219182-6, Segunda Turma, Rel. Mi. Herman Benjamin, DJ: 11/11/2008). 


\section{PROCEDIMENTO ADMINISTRATIVO}

Qualquer pessoa que tenha ciência da prática de um ato de improbidade possui legitimidade para provocar a autoridade competente em busca da devida investigação, conforme previsto no art. 14 Lei n ${ }^{\circ} 8.429 / 92$.

A representação feita pelo cidadão deverá ser apresentada de maneira escrita ou oral. Na segunda hipótese, ela deverá ser reduzida a termo e assinada, além de apresentar a qualificação do representante e do denunciado e demais informações relevantes ao ato de improbidade.

O Ministério Público e o Tribunal de Contas serão notificados sobre a instauração do processo administrativo de apuração de prática de ato de improbidade.

\section{AÇÃO JUDICIAL DE IMPROBIDADE}

Em caso de confirmação da prática de ato de improbidade, por meio do processo administrativo instaurado, a aplicação efetiva de qualquer sanção é privativa do Poder Judiciário. Não sendo possível sua realização diretamente pela Administração Pública (STF, RTJ, 195/73).

A propositura de ação de improbidade administrativa deverá ser em primeira instância sob o rito ordinário. Deverão ser aplicadas de maneira subsidiária as regras da Lei de Ação Civil Pública (Lei no 7.347/85).

Somente o Ministério Público e/ou a pessoa jurídica prejudicada têm legitimidade ativa para propor ação de improbidade administrativa. $\mathrm{Na}$ segunda hipótese, haverá a atuação obrigatória do Ministério Público como fiscal da lei, sob pena de ocorrer nulidade absoluta no processo.

Importante esclarecer que a Lei no 8.429/92 não admite qualquer tipo de transação, acordo ou conciliação na ação de improbidade administrativa.

\section{PRESCRIÇÃO}


$\mathrm{O}$ art. 23 da Lei $\mathrm{n}^{\circ}$ 8.429/92 estabelece que as ações voltadas a levar a efeito as sanções relacionadas com atos de improbidade administrativa poderão ser propostas, respeitando os seguintes prazos prescricionais:

a) Até 5 (cinco) após o término do exercício de mandato, de cargo em comissão ou de função de confiança; ou

b) dentro do prazo prescricional previsto em lei específica para faltas disciplinares puníveis com demissão a bem do serviço público, nos casos de exercício de cargo efetivo ou emprego.

Mazza (2013, p. 469) observa que "em atenção ao disposto no art. 37, $\S 5^{\circ}$, da Constituição Federal, na hipótese de o ato causar prejuízo ao erário, a ação de improbidade administrativa é imprescritível".

A imprescritibilidade da ação de improbidade administrativa está consoante ao posicionamento adotado pelo Superior Tribunal de Justiça, conforme se extrai do julgamento do REsp no 1069779-SP, conforme segue:

PROCESSUAL CIVIL E ADMINISTRATIVO. AÇÃO DE RESSARCIMENTO DE DANO AO ERÁRIO. PRESCRIÇÃO. NÃO-OCORRÊNCIA. INÉPCIA DA INICIAL NÃO CONFIGURADA. LEGITIMIDADE DO MUNICÍPIO PARA A PROPOSITURA DE AÇÃO DE IMPROBIDADE ADMINISTRATIVA. INADEQUAÇÃO DA VIA ELEITA. NÃO-CABIMENTO.

1. A empresa recorrente busca, com base no art. $17, \S$ $8^{\circ}$, da Lei 8.429/1992, a suspensão do prosseguimento de ação ordinária, na qual se apuram irregularidades na celebração e na execução do contrato para construção de unidades habitacionais.

2. O art. 23 da Lei 8.429/1992, que prevê o prazo prescricional de cinco anos para a aplicação das sanções, disciplina apenas a primeira parte do $\S 5^{\circ}$ do art. 37 da Constituição Federal, já que in fine esse mesmo dispositivo teve o cuidado de deixar "ressalvadas as respectivas ações de ressarcimento", o que é o mesmo que declarar a sua imprescritibilidade.

3. A pretensão de ressarcimento pelo prejuízo causado ao Erário é imprescritível. 
4. O Município tem legitimidade para propor Ação de Improbidade Administrativa contra ex-prefeito e outros servidores municipais. Descabido, in casu, falar em confusão entre credor e devedor, na forma do art. 381 do Código Civil.

5. Não se configura inépcia da inicial se a petição contiver a narrativa dos fatos configuradores, em tese, da improbidade administrativa e, para o que importa nesta demanda, do prejuízo aos cofres públicos.

6. Sob pena de esvaziar a utilidade da instrução e impossibilitar a apuração judicial dos ilícitos nas ações de improbidade administrativa, a petição inicial não precisa descer a minúcias do comportamento de cada um dos réus, individualmente, bastando a descrição genérica dos fatos e imputações.

7. Na hipótese dos autos, a descrição genérica dos fatos e imputações é suficiente para bem delimitar o perímetro da demanda e propiciar o pleno exercício do contraditório e da ampla defesa.

8. Impertinente a objeção de inadequação da via eleita, sob o argumento de que a licitação ocorreu e o contrato foi celebrado antes da vigência da Lei $8.429 / 1992$, quando na verdade noticiam-se irregularidades na celebração do contrato (antes da Lei da Improbidade) e também na execução do contrato (na vigência da Lei da Improbidade).

9. Inexistência de ofensa ao princípio da irretroatividade da lei. A Lei 8.429/1992 não inventou a noção de improbidade administrativa, apenas lhe conferiu regime e procedimento jurídicos próprios, com previsão expressa de novas sanções, não fixadas anteriormente.

10. Antes da Lei 8.429/1992, a prática de improbidade administrativa, sob o prisma do Direito material, já impunha ao infrator a obrigação de ressarcimento aos cofres públicos.

11. No caso, trata-se de Ação de Reparação sob o fundamento de ocorrência de dano patrimonial ao Erário, proposta pela Prefeitura de Bauru, sob o rito ordinário, em que o autor pede, expressamente na petição inicial, a condenação dos réus "ao ressarcimento dos danos sofridos pelo erário municipal, que deverão ser apurados mediante perícia 
técnica e contábil, a vista dos documentos juntados aos autos e das conclusões do Tribunal de Contas da União".

12. Possibilidade, ainda, de aplicação das sanções previstas na Lei 8.429/1992 a alterações contratuais ilegais praticadas na sua vigência, mesmo que o contrato tenha sido celebrado anteriormente. Isso porque, na aplicação do princípio tempus regit actum, em matéria de incidência da Lei 8.429/1992, considera-se o momento da prática do ato ilícito, e não a data da celebração do contrato.

13. Após a promulgação da Lei $8.429 / 1992$, as sanções nela previstas aplicam-se imediatamente a contratos com execução em andamento, mas somente se os ilícitos em questão tiverem sido praticados já na vigência do novo regime. Recurso Especial não provido. ${ }^{10}$

Assim sendo, no que concerne à ação civil pública em que se busca a condenação por danos ao erário e o respectivo ressarcimento, esta Corte considera que tal pretensão é imprescritível, com base no que dispõe o artigo 37, § 5, da Constituição da República.

\section{CONSIDERAÇÕES FINAIS}

O que se pode concluir do estudo sobre as noções gerais e sanções aplicáveis ao agente público que causa qualquer tipo de lesão ao erário ou patrimônio público a partir da Constiuição Federal, em seu artigo 37, §4º, regulamentado pela Lei $\mathrm{n}^{\circ}$ 8.429, de 2-6-1992 e alterações, conhecida como Lei de "improbidade administrativa", somada à previsão do artigo art. $5^{\circ}$, inciso LXXIII, também da Cosntituição Federal, normatizado pela Lei n' 4.717, de 28-6-1965 e alterações, que regula a "ação popular", formam dois instrumentos processuais que os agentes de todos os Poderes do Estado devem estrita obediência. Por meio do princípio da probidade e observância aos princípios prescritos na Constituição Federal, em especial o da legalidade e da moralidade, cuja inobservância ou desobediência sujeita

\footnotetext{
${ }^{10}$ STJ - Resp n⿳01069779 SP 2008/0137963-1,Segunda Turma, Rel. Min. Herman Benjamin, DJ: 18/09/2008.
} 
seu agente autor, coautor e copartícipe as sanções previstas nas referidas Leis, sempre mediante o nexo de proporcionalidade e assegurada à ampla defesa e o contraditório prévio no âmbito administrativo e judicial.

A competência para legislar sobre improbidade administrativa é privativa da União, e os diplomas jurídicos citados representa um valioso instrumento de combate à corrupção, à improbidade administrativa e tutela a probidade administrativa de todos que se acham nomeados para gerenciar e representar os Poderes do Estado, por meio de bens e patrimônio público, especialmente no momento político-administrativo por que passa nosso País.

Os sujeitos passivos são as pessoas jurídicas organizadas em categorias de Administração pública direta, Indireta, Empresas incorporadas ao patrimônio público ou de Entidade cuja criação ou custeio o erário haja concorrido ou concorra com mais de $50 \%$ do patrimônio ou da receita anual, ou seja, também é aplicável às empresas governamentais (denominadas empresas públicas e sociedades de economia mista). Também àquelas Entidades que recebam subvenção, benefício ou incentivo, fiscal ou creditício, provenientes de órgãos públicos. Trata-se das pessoas jurídicas privadas, não pertencentes ao Estado, inclusive, as pessoas jurídicas integrantes do Terceiro Setor. E as Entidades cuja criação ou custeio o erário haja concorrido ou concorra com menos de $50 \%$ do patrimônio ou da receita anual, ou seja, as empresas privadas com participação estatal, inclusive, as sociedades autorizadas ou criadas com o propósito específico de gerir parcerias público-privadas, como demonstradas.

O sujeito ativo do ato de improbidade é "qualquer agente público, servidor ou não", ou seja, atinge todas as categorias de servidores (estatutários, celetistas, temporários, agentes políticos, etc), além de ser aplicada às entidades do terceiro setor, aos funcionários e dirigentes de sindicatos, e às pessoas integrantes dos serviços sociais paraestatais (componentes do sistema " $S$ "), conforme prevê o artigo $1^{\circ}$ da Lei de "improbidade administrativa". O "agente público" é identificado por meio do artigo $2^{\circ}$ da referida Lei, compreendendo "todo aquele que exerce, ainda que transitoriamente ou sem remuneração, por eleição, nomeação, designação, contratação ou qualquer outra forma de investidura ou vínculo, mandato, cargo, emprego ou função", certamente relacionadas com as entidades citados. E por fim, o artigo $3^{\circ}$ da mesma Lei expande a tipificação da lei para outras figuras que não são qualificadas como agentes públicos, demonstrando que a lei, objeto de estudo, também é aplicada ao agente que induza ou concorra para 
a prática do ato de improbidade ou que receba algum tipo de benefício (direto ou indireto) decorrente de tal prática.

Registre-se sobre a extensão das sanções que, em caso de falecimento de um agente que tenha cometido atos de improbidade, seu espólio responderá pela infração econômica realizada até o limite do valor da herança existente, proporcionando o devido ressarcimento pelo dano, como se observar do art. $8^{\circ}$ da Lei ${ }^{\circ} 8.429 / 92$.

O ressarcimento ao erário, a punição dos agentes públicos nos casos de enriquecimento ilícito no exercício de mandato, cargo, emprego ou função na administração pública direta, indireta ou fundacional, vêm previstas na Lei ${ }^{\circ}$ 8.429/92 e alterações, bem como em qualquer das hipóteses de improbidade administrativa prevista na referida lei. Portanto, desde os atos que importam em enriquecimento ilícito, àqueles que causam prejuízo ao erário e os que atentam contra os princípios da administração pública, a Lei visa garantir, assim, a incolumidade do patrimônio público e o respeito aos princípios norteadores da administração em geral do Estado, inclusive com afastamento temporário dos quadros político-administrativos, sem prejuízo ainda da incidência de outros limites constitucionais assegurados por meio do direito de punir do Estado.

Assim, as sanções previstas a partir do artigo 37, $\$^{\circ}$ da Constituição Federal, normatizado pela Lei $n^{\circ}$ 8.429/92 e alterações, prevê como sanções a "suspensão dos direitos políticos, a perda da função pública, a indisponibilidade dos bens e o ressarcimento ao erário, na forma e gradação previstas em lei, sem prejuízo da ação penal cabível”.

Por outro lado, o artigo 12 da referida lei de "improbidade adminsitrativa", mais rígido, independentemente das sanções penais, civis e administrativas previstas na legislação específica, o responsável pelo ato de improbidade estará sujeito às seguintes cominações, que podem ser aplicadas isolada ou cumulativamente, de acordo com a gravidade do fato: a) para a hipótese do art. $9^{\circ}$, perda dos bens ou valores acrescidos ilicitamente ao patrimônio, ressarcimento integral do dano, quando houver, perda da função pública, suspensão dos direitos políticos de oito a dez anos, pagamento de multa civil de até três vezes o valor do acréscimo patrimonial e proibição de contratar com o Poder Público ou receber benefícios ou incentivos fiscais ou creditícios, direta ou indiretamente, ainda que por intermédio de pessoa jurídica da qual seja sócio majoritário, pelo prazo de dez anos; b) - para a hipótese do art. 10, ressarcimento integral do dano, perda dos bens ou valores acrescidos ilicitamente ao patrimônio, se concorrer esta 
circunstância, perda da função pública, suspensão dos direitos políticos de cinco a oito anos, pagamento de multa civil de até duas vezes o valor do dano e proibição de contratar com o Poder Público ou receber benefícios ou incentivos fiscais ou creditícios, direta ou indiretamente, ainda que por intermédio de pessoa jurídica da qual seja sócio majoritário, pelo prazo de cinco anos; c) - para a hipótese do art. 11, ressarcimento integral do dano, se houver, perda da função pública, suspensão dos direitos políticos de três a cinco anos, pagamento de multa civil de até cem vezes o valor da remuneração percebida pelo agente e proibição de contratar com o Poder Público ou receber benefícios ou incentivos fiscais ou creditícios, direta ou indiretamente, ainda que por intermédio de pessoa jurídica da qual seja sócio majoritário, pelo prazo de três anos; para hipóteses do art. 10-A, perda da função pública, suspensão dos direitos políticos de 5 (cinco) a 8 (oito) anos e multa civil de até 3 (três) vezes o valor do benefício financeiro ou tributário concedido, sempre fixadas levando em conta a extensão do dano causado, assim como o proveito patrimonial obtido pelo agente.

A Ação Popular, que pode ser proposta por qualquer cidadão (qualquer pessoa física em pleno gozo de seus direitos políticos), o pedido de sanção deve ser a anulação do ato lesivo à moralidade e a condenação do agente responsável ao ressarcimento pelas perdas e danos que causou, conforme previsão do art. 11 da Lei no 4.717/65.

Face à definição e conceituação de "agente político", abrangendo os Chefes dos Poderes Executivos federal, estadual e municipal, os Ministros e Secretários de Estado, além de Senadores, Deputados e Vereadores, inclusive Membros do Poder Judiciário e do Órgão do Ministério Público, bem como Conselheiros e Ministros de Tribunais de Contas, surgiu determinado conflido de entendimento ou de interpretação, justamente acerca da aplicação ou não da Lei $n^{\circ}$ 8.429/92 aos agentes políticos, uma vez que o artigo 23 da referida legislação trata sobre o "exercício de mandato". E como a Constituição Federal não admite a concorrência entre dois regimes de responsabilidade político-administrativa para os agentes políticos, nos termos do previsto no art. $37, \S 4^{\circ}$ (regulado pela Lei $\mathrm{n}^{\circ} 8.429 / 1992$ ) e o regime fixado no art. 102, I, c, (disciplinado pela Lei $\left.{ }^{\circ} 1.079 / 1950\right)$, o mais alta Corte do País enendeu, após oscilar seu posicionamento, reconheceu a aplicação ao Prefeito Municipal, uniformizando seu entendimento de que é aplicável sim a Lei de "improbidade administrativa" ao Prefeito Municipal, conforme julgamento do Supremo Tribunal Federal proferida no ARE 644.749. 
Logo, os prefeitos, embora também sejam agentes políticos, não se enquadram na ressalva, e, logo, se submetem à lei de improbidade administrativa, sujeitando-se, ainda, à ação penal por crime de responsabilidade, na forma do Decreto-Lei $n^{\circ}$ 201/67, em decorrência do mesmo fato.

Em relação à declaração de bens, o artigo 13 da Lei no 8.429/92 impõe o dever de todos os agentes públicos, anualmente, apresentação de declaração dos bens e valores que compõem o seu patrimônio privado, a fim de ser arquivada no serviço de pessoal competente, devendo compreender imóveis, móveis, semoventes, dinheiro, títulos, ações, e qualquer outra espécie de bens e valores patrimoniais, localizado no País ou no exterior e, quando for o caso, abrangerá os bens e valores patrimoniais do cônjuge ou companheiro, dos filhos e de outras pessoas que vivam sob a dependência econômica do declarante, excluídos apenas os objetos e utensílios de uso doméstico, na forma do $\S 1^{\circ}$ do art. 13 da Lei $n^{\circ}$ 8.429/92. E havendo recusa no fornecimento da declaração, ou a prestação de qualquer informação falsa resultará na demissão do agente público, além da aplicação das demais sanções cabíveis.

Conclui-se também até então pela inaplicabilidade do princípio da insignificância e a teoria dos delitos de bagatela para os atos de improbidade administrativa, conforme decisão do Superior Tribunal de Justiça, uma vez que referente aos atos de improbidade está em jogo à moralidade administrativa, cuja ofensa não estaria vinculada exclusivamente nos parâmetros econômicos.

Por fim, por meio do procedimento de investigação é permitido a qualquer pessoa física ou jurídica provocar os Órgãos e Poderes competentes para tomarem providências, nos termos do art. 14 Lei $n^{\circ} 8.429 / 92$, podendo ser escrita ou oral a representação, certo que a última deverá ser reduzida a termo e assinada, além de apresentar a qualificação do representante e do denunciado e demais informações relevantes ao ato de improbidade, sendo dever a comunicação ao Ministério Público e o Tribunal de Contas à notificação sobre a instauração do processo administrativo de apuração de prática de ato de improbidade. E no âmbido judicial, em caso de confirmação da prática de ato de improbidade, por meio do processo administrativo instaurado, a aplicação efetiva de qualquer sanção é privativa do Poder Judiciário, não sendo possível sua realização diretamente pela Administração Pública, conforme julgado do STF, RTJ, 195/73, surgindo o dever de ajuizar a ação de improbidade administrativa em primeira instância sob o rito ordinário, aplicando-se a Lei de "improbidade administrativa" e de forma subsidiária as regras da Lei de Ação Civil Pública, Lei 
$\mathrm{n}^{\mathrm{o}} 7.347 / 85$, por seus legitimados, observados os prazos prescricionais previsto no artigo 23 da Lei $n^{\circ} 8.429 / 92$, e para as hipóteses de ato causar prejuízo ao erário, à ação de improbidade administrativa é imprescritível, segundo o posicionamento até então pelo Superior Tribunal de Justiça, segundo o julgamento do REsp n ${ }^{\circ} 1069779-S P$.

\section{REFERÊNCIAS BIBLIOGRÁFICAS}

BITENCOURT NETO, Eurico. Improbidade administrativa e violação de princípios. Belo Horizonte: Del Rey, 2005. p. 129.

CAHALI, Yussef Said. Responsabilidade Civil do Estado. $2^{a}$ ed. São Paulo: Malheiros, 1996.

DI PIETRO. Maria Sylvia Zanella. Direito Administrativo. $13^{a}$ ed. São Paulo: Atlas, 2001.

FARIA, Edimur Ferreira de. Curso de Direito Administrativo Positivo. $4^{\text {a }}$ ed. Belo Horizonte: Del Rey, 2001.

FAZZIO JÚNIOR, Waldo. Improbidade Administrativa e Crimes de Prefeitos. São Paulo: Editora Atlas. 2012. p. 148.

FIGUEIREDO, Lúcia Valle. Curso de Direito Administrativo. $6^{a}$ ed.. São Paulo: Malheiros, 2003.

FURTADO, Lucas Rocha Furtado. Curso de Direito Administrativo. Belo Horizonte: Fórum, 2007.

MAZZA, Alexandre, Manual de Direito Administrativo. $3^{\mathrm{a}}$ ed. São Paulo: Saraiva, 2013.

MELLO, Celso Antonio Bandeira de. Curso de Direito Administrativo. São Paulo: Malheiros, 1996.

NEIVA, José Antônio Lisboa. Improbidade administrativa: legislação comentada artigo por artigo- doutrina, legislação e jurisprudência. $2^{\mathrm{a}}$ edição, Niterói- RJ: Ed. Impetus, 2011. p. 66.

OLIVEIRA, Ruth Helena Pimentel de. Entidades Prestadoras de Serviços Públicos e Responsabilidade Extracontratual, São Paulo: Atlas, 2003. 